\title{
PEMBERIAN MAKANAN TAMBAHAN IBU HAMIL KEK DI PUSKESMAS KARYA WANITA PEKANBARU
}

\author{
Mita Puspitasari ${ }^{1 凶}$, Mitra $^{2}$, Tin Gustina ${ }^{3}$, Novita Rany ${ }^{4}$, Zulfayeni $^{5}$ \\ 1,2,3,4Program Studi Magister Kesehatan Masyarakat STIKes Hang Tuah Pekanbaru \\ ${ }^{5}$ Dinas Kesehatan Provinsi Riau
}

\section{ARTICLE INFO \\ Article history \\ Submitted : 2020-10-09 \\ Revised : 2021-12-20 \\ Accepted : 2021-12-31 \\ Keywords: \\ Chronic energy deficiency Pregnant women Supplementary feeding}

\section{Kata Kunci:}

Ibu Hamil

Kekurangan Energi Kronik $P M T$

\begin{abstract}
Chronic Energy Deficiency in pregnant women is a condition of pregnant women due to an imbalance in the intake of energy and protein nutrients, so that the substances the body needs are not fulfilled. Incident chronic energy deficiency in pregnant women have a risk of abortion, bleeding, prolonged labor, infection, low birth weight baby, birth defects, and causes of death indirectly. An attemt to resolve the incidence of malnutrition in pregnant women in chronic energy deficiency with supplementary food. Type of qualitative research. Research informants were pregnant women chronic energy deficiency, nutrition staff, midwives, health promotion officers, and cadres. Research results are the knowledge of pregnant women in chronic energy deficiency about supplementary feeding is stil lacking, the attitudes of pregnant women in chronic energy deficiency and their husband's support about supplementary feeding are already good, compliance of pregnant women in chronic energy deficiency is still lacking, acceptance of pregnant women in chronic energy deficiency about supplementary feeding is stil lacking, delivery of information when counseling needs to be improved by using the contemporary method, distribution of supplementary feeding for Puskesmas officers in collaboration with cadres. Advice doing technical guidance to health workers about supplementary feeding, health workers increase again in providing information related to supplementary feeding, provide information using digital media such as video, made a special trick of setting an alarm as a reminder to consume supplementary feeding, make derivate technical guidelines from the ministry of helath according to conditions in the field.

Kekurangan Energi Kronik pada ibu hamil merupakan kondisi ibu hamil karena ketidakseimbangan asupan zat gizi energi dan protein, sehingga zat yang dibutuhkan tubuh tidak tercukupi. Kejadian kekurangan energi kronik pada ibu hamil beresiko terjadinya abortus, perdarahan, partus lama, infeksi, berat bayi lahir rendah, cacat lahir, dan penyebab kematian maternal secara tidak langsung. Upaya untuk mengatasi kejadian kekurangan gizi pada ibu hamil kekurangan energi kronik dengan Pemberian Makanan Tambahan. Jenis penelitian kualitatif. Informan penelitian yaitu ibu hamil kekurangan energi kronik, staf gizi, bidan, petugas promkes, dan kader. Hasil penelitian ini pengetahuan ibu hamil kekurangan energi kronik tentang pemberian makanan tambahan masih kurang, sikap ibu hamil kekurangan energi kronik dan dukungan suami terkait pemberian makanan tambahan sudah bagus, kepatuhan ibu hamil kekurangan energi kronik yang masih kurang, penerimaan ibu hamil kekurangan energi kronik terkait pemberian makanan tambahan masih kurang, penyampaian informasi ketika konseling perlu ditingkatkan lagi dengan menggunakan media digital, untuk pendistribusian pemberian makanan tambahan petugas puskesmas berkolaborasi dengan kader. Saran melakukan bimbingan teknik secara rinci kepada petugas kesehatan tentang pemberian makanan tambahan, petugas kesehatan meningkatkan lagi dalam pemberian informasi terkait pemberian makanan tambahan, memberikan informasi dengan menggunakan media digital seperti video, membuat trik khusus berupa menyetel alarm sebagai pengingat untuk mengkonsumsi pemberian makanan tambahan, membuat turunan juknis dari kemenkes sesuai kondisi di lapangan.
\end{abstract}

Corresponding Author:

Mita Puspitasari

STIKes Hang Tuah Pekanbaru

Telp. 08117536613

Email: puspitasarimita003@gmail.com 


\section{PENDAHULUAN}

Kekurangan Energi Kronik (KEK) pada ibu hamil merupakan kondisi yang dialami ibu hamil karena ketidakseimbangan asupan gizi energi dan protein, sehingga zat yang dibutuhkan tubuh tidak tercukupi. Kurangnya asupan gizi pada ibu hamil selain membahayakan kesehatan ibu, juga akan berdampak pada terlambatnya pertumbuhan dan perkembangan janin. Kecukupan asupan nutrisi pada ibu hamil dilihat dari status gizi ibu hamil salah satunya dapat digambarkan dengan ukuran lingkar lengan atas (LILA) (Andriani, 2015). Risiko KEK dapat dicegah dengan menjaga status gizi ibu hamil dengan LILA tidak kurang dari 23,5 cm (Azizah \& Adriani, 2018). Kejadian KEK pada ibu hamil memiliki risiko terjadinya abortus, perdarahan, partus lama, infeksi, BBLR, prematur, lahir cacat, dan penyebab kematian maternal secara tidak langsung (Andiyani \& Susilawati, 2019).

Kejadian KEK pada ibu hamil dapat dicegah dengan pemberian makanan tambahan (PMT). PMT dimaksudkan berbasis bahan makanan lokal dengan menu khas daerah yang disesuaikan dengan kondisi setempat. PMT yang diberikan kepada ibu hamil dalam hal ini hanya untuk sebagai tambahan makanan atau cemilan, disaat ibu hamil tidak nafsu makan maka PMT menjadi alternatif untuk pemenuhan nutrisi ibu hamil, pada trimester 1 PMT yang dikonsumsi yaitu 2 keping/hari, sedangkan pada trimester II dan III PMT yang dikonsumsi 3 keping/hari (Kementerian Kesehatan RI, 2017).

Angka kejadian KEK di negaranegara berkembang seperti Bangladesh, India, Indonesia, Myanmar, Nepal, Srilangka, dan Thailand adalah $15-47 \%$. Negara yang tertinggi adalah Bangladesh yaitu $47 \%$, sedangkan Indonesia menjadi urutan ke-4 terbesar setelah India dengan Prevalensi 35,5\% (Manik \& Rindu, 2017). Angka kejadian KEK pada ibu hamil di Indonesia berdasarkan data Riset Kesehatan Dasar tahun 2013 sebesar 24,2\% atau sekitar 76 juta ibu hamil (Riskesdas, 2015). Kemudian pada tahun 2018 angka kejadian KEK pada ibu hamil mengalami penurunan yaitu dari 24,2 \% menjadi 17,3\% (Riskesdas, 2018). Berdasarkan survei awal yang dilakukan di Dinkes Kota Pekanbaru bahwasanya angka kejadian KEK pada ibu hamil di Kota
Pekanbaru tahun 2018 yaitu sebesar 3\% (773 orang) dari total keseluruhan sebanyak 24.228 ibu hamil yang melakukan pemeriksaan (Dinas Kesehatan Kota, 2018). Data Dinkes Provinsi Riau tahun 2018 tercatat bahwasanya angka kejadian Ibu Hamil KEK di Kota Pekanbaru berada pada urutan ke 7 dari 12 kota di Provinsi Riau (Dinas Kesehatan Provinsi, 2018).

Berdasarkan penelitian (Mangalik et al., 2019) menyatakan bahwasanya pendistribusian PMT belum optimal, kemudian kurangnya kesadaran ibu hamil untuk melakukan pemeriksaan kesehatan dan makanan tambahan tidak dihabiskan oleh ibu hamil. Indikator RPJMN dan Renstra tahun 2020 persentase ibu hamil KEK sebesar 16\%. Di Puskesmas Karya Wanita Pekanbaru angka kejadian KEK setiap tahunnya mengalami peningkatan, di tahun 2020 pada bulan Januari - Juli angka kejadian KEK sebesar 9,4\%. Meskipun angka tersebut masih di bawah angka Resntra namun ini juga merupakan suatu masalah, maka peneliti ingin memperoleh informasi yang komprehensif tentang Pemberian Makanan Tambahan pada Ibu Hamil Kekurangan Energi Kronik di Puskesmas Karya Wanita Pekanbaru Tahun 2020.

\section{METODE PENELITIAN}

\section{Jenis Penelitian}

Penelitian ini menggunakan metode kualitatif dengan desain penelitian fenomenologi.

\section{Lokasi dan Waktu Penelitian}

Penelitian ini dilakukan pada bulan Maret Agustus 2020 di Puskesmas Karya Wanita Pekanbaru.

\section{Informan Penelitian}

Informan penelitian dibagi menjadi 2 kelompok yaitu informan utama ibu hamil KEK berjumlah 5 orang dan Informan pendukung kader 2 orang, staf gizi puskesmas, bidan, petugas promosi kesehatan masing-masing 1 orang. Teknik penentuan informan menggunakan purposive sampling.

\section{Pengumpulan Data}

Data yang digunakan adalah data primer dan data sekunder, data primer diperoleh dari wawancara mendalam dengan ibu hamil KEK. sedangkan data sekunder diperoleh dari pencatatan staf gizi dan bidan.
Jurnal Kesehatan 
Wawancara dilakukan melalui telepon seluler dan langsung turun ke lapangan namun tetap menjaga protokol kesehatan.

\section{Keabsahan Data}

Pengujian keabsahan data pada penelitian ini menggunakan triangulasi yaitu triangulasi sumber dan metode. Triangulasi dilakukan dengan cara mengecek kebenaran data antara petugas kesehatan dan juga ibu hamil KEK.

\section{Pengolahan dan Analisis Data}

Analisis data data meliputi tahap reduksi data, tahap penyajian data, dan tahap penarikan kesimpulan. Selain itu penelitian ini mempunyai landasan yang kuat, bermanfaat, akan dilakukan sesuai dengan prosedur kerja yang telah ditetapkan, tidak membahayakan peneliti dan subjek penelitian. Serta penelitian ini sudah memenuhi syarat etik dan lolos kaji etik oleh Komisi Etik STIKes Hang Tuah Pekanbaru dengan Nomor: 319/KEPK/STIKesHTP/VI/2020.

\section{HASIL PENELITIAN}

\section{Pengetahuan Ibu Hamil KEK terhadap Perilaku Konsumsi PMT}

Semua ibu hamil sudah mendapatkan PMT berupa biskuit yang setiap bulannya diberikan 1 kardus, 4 dari 5 ibu hamil KEK sudah mengetahui terkait program PMT yang disampaikan oleh pihak Puskesmas Karya Wanita ketika melakukan pemeriksaan di Puskesmas. Selain itu 4 dari 5 ibu hamil KEK juga mengatakan bahwasanya sangat penting bagi ibu hamil mengonsumsi PMT ini karena baik untuk kesehatan ibu maupun bayi. Namun untuk jangka waktu mengonsumsi PMT dari 5 ibu hamil KEK tidak ada yang mengetahui sampai kapan mereka harus mengonsumsi PMT yang telah diberikan dan biasanya kendala ketika mereka mengonsumsi PMT yaitu lupa. Teknik atau cara mengonsumsi PMT 4 dari 5 ibu hamil mengonsumsi PMT dengan susu maupun teh dengan banyak biskuit 3 keping setiap harinya. Ibu hamil KEK juga mengatakan bahwasanya PMT ini sangat berpengaruh bagi pertambahan berat badan mereka.

"Sampai berat badan ibu kembali
normal, kendalanya lupa" (IU 1).

"Sampai usia kehamilan 8 bulan, kendalanya lupa" (IU 2).

"Berapa lamanya itu tidak tahu ya, selagi masih dikasih tetap saya konsumsi, kendalanya bosan” (IU 3).

"Sampai waktunya melahirkan, dikarenakan saat melahirkan membutuhkan banyak tenaga" (IU 4).

"Sampai usia kehamilan 6 atau 7 bulan" (IU 5).

Sementara itu jawaban dari informan utama dikonfirmasi kepada informan pendukung yaitu staf gizi dan bidan di Puskesmas Karya Wanita mengatakan bahwasanya ibu hamil KEK mendapatkan makanan tambahan selama 3 bulan atau 90 hari.

Menurut peneliti pengetahuan ibu terkait jangka waktu mengonsumsi PMT masih kurang dilihat pada saat wawancara masih adanya kebingungan dari wajah informan ketika ditanyakan terkait jangka waktu mengonsumsi MT. Hal ini membuktikan bahwa ibu hamil KEK penerima paket makanan tambahan di wilayah kerja Puskesmas Karya Wanita masih belum memahami dengan benar mengenai PMT tersebut.

Tabel 1. Karakteristik Informan Utama

\begin{tabular}{cccccc}
\hline $\begin{array}{c}\text { Kode } \\
\text { Informan }\end{array}$ & Umur & Pendidikan & Pekerjaan & $\begin{array}{c}\text { Usia Kehamilan } \\
\text { Saat Menerima PMT }\end{array}$ & LILA \\
\hline IU 1 & 27 Tahun & SMA & Guru Paud & 16 minggu & $22,5 \mathrm{~cm}$ \\
IU 2 & 27 Tahun & SMK & IRT & 25 minggu & $22 \mathrm{~cm}$ \\
IU 3 & 23 Tahun & SMP & IRT & 12 minggu & $22 \mathrm{~cm}$ \\
IU 4 & 34 Tahun & SLTP & IRT & 25 minggu & $23 \mathrm{~cm}$ \\
IU 5 & 40 Tahun & SMA & IRT & 13 minggu & $22 \mathrm{~cm}$ \\
\hline
\end{tabular}




\section{Sikap Ibu Hamil KEK terhadap Perilaku Konsumsi PMT}

Semua ibu hamil KEK yang menjadi informan setuju dengan adanya pemberian makanan tambahan yang diselenggarakan oleh pihak Puskesmas, dan mengatakan bahwasanya PMT ini sangat penting untuk ibu hamil yang mengalami kekurangan energi kronik. Selain itu 3 dari 5 ibu hamil KEK juga mengatakan bahwasanya jika mereka tidak mendapatkan PMT mereka merasa kecewa dan sedih. Namun ibu hamil KEK juga berpendapat bahwasanya jika ada ibu hamil yang tidak mau mengonsumsi PMT itu wajar, dikarenakan penerimaan dari setiap ibu hamil itu berbedabeda.

"Ada setujunya, terkadang bosan dan lupa. Keseringannya lupa” (IU 1).

"Gak setuju, karna kita kan sudah mendapatkan itu dari pemerintah. Ya salah saja jika tidak dimakan" (IU 2).

"Wajar-wajar saja sih, ya terkadang tidak semua orang yang mau makan roti ibu hamil, apalagi orang hamil seleranya berbeda-beda. Ada yang mau makannya ada yang tidak. Dikasih pun terkadang percuma tidak dikonsumsinya kan" (IU $3)$.

"Tidak, karna kan kalau kita dikasih makanan tambahan kita semakin sehat, bayinya pun sehat. Kalau biasanya kan kebanyaan kalau kita tidak dibantu makanan tambahan kan bayinya kurang gizi begitu” (IU 4).

"Setuju juga kalau misalnya dia bisa menerap kan pola hidup sehat dalam rumahnya setuju juga kalau dia tidak mengkonsumsi makanan tambahan, tapi alangkah baiknya dimakan juga sebagai cemilan itu tidak masalah" (IU 5).

Selain itu berdasarkan pernyataan oleh kader mengenai semangat ibu hamil KEK terhadap adanya PMT didapatkan hasil bahwasanya ibu hamil KEK memberikan respon yang baik terhadap program PMT ini, dan ada juga ibu hamil KEK yang langsung pergi ke Puskesmas untuk mengambil makanan tambahannya.

Dari pernyataan diatas, peneliti menyimpulkan bahwasanya sikap ibu hamil KEK terkait adanya program PMT ini sudah baik, dikarenakan adanya respon positif dari 5 orang ibu hamil KEK tersebut.

Tabel 2. Karakteristik Informan Pendukung

\begin{tabular}{ccccc}
\hline Kode Informan & Usia & Pendidikan & Pekerjaan & Jabatan \\
\hline IP 1 & 50 Tahun & D3 Gizi & PNS & PJ Gizi \\
IP 2 & 33 Tahun & D3 Kebidanan & PNS & PJ KIA \\
IP 3 & 40 Tahun & S1 Kesmas & PNS & PJ Promkes \\
IP 4 & 67 Tahun & SMK Gizi & Kader & Ketua Kader \\
IP 5 & 51 Tahun & SMA & Kader & Ketua Kader \\
\hline
\end{tabular}

\section{Dukungan Suami Ibu Hamil KEK terhadap} Perilaku Konsumsi PMT

Berdasarkan hasil wawancara dengan informan utama mengenai dukungan suami terhadap PMT yang didapatkan, 5 ibu hamil KEK mengatakan bahwasanya suami mereka senang dan sangat mendukung dengan adanya PMT yang diberikan oleh pihak Puskesmas. Kemudian dukungan suami dalam meningkatkan kesehatan ibu selama hamil khususnya berat badan ibu didapatkan hasil sebagian besar ibu hamil mengatakan bahwasanya suami memberikan dukungan seperti motivasi serta dukungan secara langsung terkait memilih makanan yang sehat.

"Tidak masalah oleh suami saya. Terkadang dia juga ingin mencoba biskuitnya. Terus saya bilang, itu 3 keping per hari, tidak boleh dikasih sama orang lain saya bilang gitu.. Terus dia mengambil 1 kalau tidak salah saya dan mengatakan jika biskuitnya enak. Dan menyarankan makannya dengan susu jika tidak enak. Selain itu dia sering pokoknya 
batasin yang sehat sama gak sehat aja sih mbak" (IU 1).

"Senang. Bersyukur ada program seperti ini. Kemudian juga ada sih suami suka beliin makanan, terus bertanya saya ingin makan apa” (IU 2).

"Dia sangat mendukung sekali, selain itu dia juga selalu mengingatkan untuk mengkonsumsi makanan bergizi seperti buah, ikan, dan sayuran"(IU 3).

"Baguslah dapat bantuan katanya kan bisa menambah berat badan si bayi dan ibu hamilnya, kemudian selalu mengingatkan agar jangan lupa mengkonsumsi makanan tambahannya" (IU 4).

"Dia senang juga, karena terkadang suami mau juga makan biskuitnya, dia bilang rasanya enak., suami jadi merasa tidak terbebankan terkadang saya suka jajan, tapi dengan adanya itu jadi terbantu, karena pengalaman saya juga tengah malam suka lapar, jadi dari pada suami pergi beli keluar mending makan biskuit ini saja. Menjadi terbantu juga suaminya. Selain mengkonsumsi biskuit suami juga selalu mengingatkan untuk makan banyak dan menyarankan untuk mengganti menu makanan agar tidak bosan” (IU 5).

Selain itu berdasarkan hasil wawancara dengan kader didapatkan hasil bahwasanya respon suami terhadap PMT sudah bagus dan juga dukungan suami dalam meningkatkan kesehatan ibu sangat baik, misalnya suami ikut serta dalam mengambil PMT ke rumah kader. Hal ini dapat dilihat dari hasil wawancara berikut ini:

"Respon suaminya baik sih, terkadang suaminya juga bertanya manfaat biskuit itu apa. Suaminya sangat mendukung menurut ibu, terkadang jika biskuitnya sudah habis malah suaminya yang menjemput ke rumah ibu" (IP 4).

"Menurut saya respon suaminya sudah bagus. Suaminya juga mendukung, dan terkadang ketika saya tidak sempat mengantarkan ke rumah ibu hamil KEK malah suaminya yang menjemput dan bertanya kapan bisa diambil lagi biskuitnya" (IP 5).

Berdasarkan pernyataan di atas peneliti menyimpulkan bahwasanya dukungan suami yang diterima oleh ibu hamil KEK sudah baik dalam meningkatkan kesehatan ibu hamil tersebut. Namun mungkin perlu ditambahkan seperti peran serta suami dalam mengikuti konseling yang diberikan oleh pihak Puskesmas disaat ibu hamil melakukan pemeriksaan kehamilan.

\section{Kepatuhan Ibu Hamil KEK terhadap Perilaku Konsumsi PMT}

Berdasarkan hasil wawancara mendalam mengenai seperti apa ibu hamil mengonsumsi makanan tambahan yang telah diberikan, 3 dari 5 ibu hamil KEK menjawab bahwasanya mereka rutin mengonsumsi PMT tersebut dan tidak pernah lupa, namun 2 dari 5 ibu hamil KEK mengatakan kendala dalam mengonsumsi PMT ini adalah lupa. Selain itu 3 dari 5 ibu hamil KEK juga mengatakan bahwasanya makanan tambahan yang dikonsumsi tidak pernah bersisa selalu habis. Hal ini dapat dilihat dari hasil wawancara berikut ini:

"Pertama kali saya menerima makanan tambahan ini pada bulan Mei, dalam 3 minggu pertama itu saya selalu rutin mengonsumsinya yaitu pagi, siang, dan malam. Setelah melewati 3 minggu dikarenakan kegiatan saya sehari-hari bekerja, saya selalu lupa untuk mengonsumsi makanan tambahan tersebut. Biasanya jika saya sedang ada kerjaan saya makan setengahnya dahulu, sisanya saya masukin toples" (IU 1).

"Saya menerima makanan tambahan itu pertama kali pada bulan 5, konsumsi setiap pagi, siang, dan malam. Namun terkadang pernah juga lupa memakannya. Pernah lupa namun saya konsumsi hari besoknya. Terkadang karena sudah kenyang" (IU 2).

"Saya selalu rutin mengonsumsinya selagi biskuit nya masih ada. Tidak pernah bersisa karena kan isinya cuma 3, setidaknya 3 itu pasti habis” (IU 3). 
"Saya menerima makanan tambahan ini 2 minggu yang lalu, selalu rutin setiap hari saya makan tidak pernah lupa. Tidak pernah lupa selalu habis" (IU 4).

"Saya selalu rutin mengonsumsinya setiap hari, namun karna saat ini makanan tambahannya sudah tidak ada jadi saya tidak konsumsi lagi dikarenakan wabah covid ini, terakhir saya mengambil bulan 6 kemaren. Saya selalu mengonsumsi biskuit itu 4 keping dalam sehari, tidak pernah lupa" (IU 5).

Berdasarkan hasil observasi yang dilakukan oleh peneliti 2 dari 5 ibu hamil KEK tidak selalu mengonsumsi MT yang telah diberikan, hal ini dapat dilihat pada saat penelitian berlangsung peneliti menemukan ketidaksesuaian antara pernyataan yang disampaikan oleh informan dengan jumlah biskuit informan, maksudnya yang seharusnya biskuit tersebut sudah habis dalam waktu 1 bulan namun kenyataannya masih ada biskuit yang tersisa.

\section{Penerimaan Ibu Hamil KEK terhadap Perilaku Konsumsi PMT}

Selanjutnya berdasarkan hasil wawancara mengenai bagaimana bentuk makanan tambahan yang diterima mulai dari tekstur, warna dan rasa didapatkan hasil 3 dari 5 ibu hamil KEK mengatakan bahwasanya tidak ada masalah dalam bentuk dan teksturnya, rasanya juga enak. Namun 2 dari 5 ibu hamil KEK mengatakan bahwasanya rasa biskuit tersebut terlalu manis dan bikin enek, mereka mengatakan bahwa mereka pecinta rasa coklat. Hal ini dapat dilihat dari hasil wawancara berikut ini:

"Karena saya kurang suka selai stroberry jadinya selainya tidak saya makan. Kalau untuk teksturnya tidak masalah sih. Rasa tidak bikin enek" (IU 1).

"Gurih dan rapuh, bentuknya juga bagus. Tidak bikin enek" (IU 2).

"Selainya itu rasa stroberry, kalau rotinya seperti slai olai. Terlalu manis dan sedikit enek kalau dimakan" (IU 3).
"Biskuitnya rasa stroberry, harum, dan tidak bikin enek" (IU 4).

"Bentuknya bagus, tekstur nya seperti kue kukis itu garing. Saya tidak terlalu suka selainya terkadang saya berikan kepada anak saya, karena saya pecinta rasa coklat"”, (IU 5).

Namun menurut informan pendukung mengenai bagaimana ibu hamil dalam mengambil makanan tambahan tersebut apakah sudah sesuai jadwal dan apakah ada yang tidak mengambil didapatkan hasil bahwa daya terima dari ibu hamil itu beda-beda, jika mereka suka mereka akan datang tepat waktu atau ada juga yang datang sedikit terlambat, namun jika mereka tidak suka mereka tidak akan datang lagi.

\section{Dukungan Tenaga Kesehatan terhadap Perilaku Konsumsi PMT (KIE)}

Hasil penelitian mengenai penjelasan dari tenaga kesehatan terkait PMT bahwasanya 4 dari 5 ibu hamil KEK mengatakan penjelasan yang disampaikan pihak Puskesmas Karya Wanita sudah bagus, pihak puskesmas menjelaskan terkait gizi ibu hamil serta menjelaskan mengenai makanan tambahan. Kemudian terkait informasi seperti apa yang telah didapatkan dari tenaga kesehatan mengenai PMT, didapatkan hasil bahwasanya petugas kesehatan memberikan penjelasan mengenai kondisi ibu kemudian menjelaskan bagaimana mengonsumsi makanan tambahan tersebut, 4 dari 5 ibu hamil KEK mengatakan informasi yang diberikan melalui konseling saja.

Selanjutnya mengenai informasi sebelum pelaksanaan PMT didapatkan hasil bahwasanya 4 dari 5 ibu hamil KEK mengatakan tidak pernah mendapatkan informasi sebelum pelaksanaan PMT tersebut. Selain itu mengenai motivasi yang biasanya dilakukan oleh petugas Puskesmas maupun kader terkait PMT ini 4 dari 5 ibu hamil KEK mengatakan bahwasanya petugas kesehatan maupun kader ada memberikan motivasi agar ibu hamil mau mengkonsumsi makanan tambahan yang telah diberikan.

"Saya diberikan penjelasan jika ibu hamil berat badannya kurang dapat 
berdampak pada anaknya. Saat itu hanya konseling saja” (IU 1).

"Informasi yang diberikan hanya sekedar mengenai LILA yang kurang saja dengan cara konseling” (IU 2).

"Saat itu petugas mengatakan bahwasanya biskuit ini bagus untuk kesehatan dan perkembangan bayi. Pemberian penyuluhan tidak hanya konseling saja” (IU 3).

"Tidak mendapatkan informasi dari pihak Puskesmas, hanya dari kader" (IU 4).

"Informasi yang saat ini sering didapatkan hanya dari konseling, penyuluhan belum ada" (IU 5).

Berdasarkan wawancara mendalam dengan informan pendukung yaitu staf gizi, bidan KIA, dan petugas promosi kesehatan mengenai informasi yang diberikan petugas kesehatan sebelum pemberian makanan tambahan, bahwasanya 3 dari 3 orang petugas kesehatan mengatakan setiap ibu hamil yang kontak dengan petugas akan diberikan informasi terkait gizi seimbang, baik itu ibu hamil KEK maupun tidak KEK. Namun mengenai informasi pengambilan PMT 2 dari 3 petugas kesehatan mengatakan informasi yang diberikan mengenai tujuan pemberian PMT. Pemberian informasi ada melalui kader jika ibu hamil tidak periksa ke Puskesmas, dan ada juga kerjasama dengan faskes seperti bidan praktik mandiri, kemudian ada grup khusus ibu hamil.

Selain itu kader juga mengatakan bahwasanya ibu hamil yang berada diwilayah kerja mereka sudah mendapatkan informasi terkait PMT tersebut. Kemudian mengenai motivasi yang diberikan kepada ibu hamil agar ibu hamil bersedia mengikuti program PMT ini kader mengatakan bahwasanya kader selalu mengingatkan ibu hamil untuk melakukan pemeriksaan ke Puskesmas, kemudian menjelaskan bahwasanya ada pemberian makanan tambahan juga.

Kemudian berdasarkan hasil observasi yang dilakukan oleh peneliti, bahwasanya tenaga kesehatan di saat memberikan konseling kepada ibu hamil KEK hanya menggunakan buku KIA saja, tidak adanya media pendukung lainnya dalam menjelaskan informasi yang diberikan. Berdasarkan pernyataan diatas dapat dilihat bahwasanya masih kurangnya media dalam pemberian informasi kepada ibu hamil KEK terkait PMT sehingga mengakibatkan masih kurangnya pemahaman ibu hamil KEK terkait PMT tersebut.

\section{Pendistribusian PMT}

Pada masa pandemi covid-19 ini sistem pendistribusian PMT mengalami keterhambatan dikarenakan ibu hamil tidak boleh datang ke Puskesmas, sehingga banyaknya penumpukan biskuit di gudang. Namun pada bulan Juli tahun 2020 pihak Puskesmas Karya Wanita yaitu petugas gizi meminta bantuan kader posyandu untuk mendata ibu hamil yang ada diwilayah kerja kader tersebut, setelah itu pihak Puskesmas langsung turun menggunakan Ambulance untuk membagi-bagikan biskuit kepada ibu hamil di wilayah kerja Puskesmas Karya Wanita. Hal ini dapat dilihat dari hasil wawancara berikut ini:

"Sekarang ibu hamil tidak dianjurkan untuk ke Puskesmas, karena PMT masih sedikit yang terdistribusi akhirnya saya minta tolong kepada kader posyandu untuk mendata ibu hamil di wilayah mereka, kemudian saya turun langsung menggunakan ambulance ke setiap $R W$. Jadi sebetulnya PMT ni yang dari pemerintah syaratnya kan ibu hamil KEK, tapi ternyata PMT ni jumlahnya sangat besar sekali, sangat banyak jumlahnya. Jadi dari pada mubazir istilahnya, sетиa ibu hamil kami kasih PMT ini. Memang prioritas tetap ibu hamil KEK” (IP 1).

"Ada saya dengar mereka turun karena stok PMT yang masih sangat banyak, takutnya expired" (IP 2).

\section{PEMBAHASAN}

\section{Pengetahuan Ibu Hamil KEK terhadap Perilaku Konsumsi PMT}

Masih banyaknya ibu hamil KEK yang tidak mengetahui terkait jangka waktu mengonsumsi makanan tambahan, hal ini salah satunya dipengaruhi karena informasi yang diberikan petugas kesehatan kurang lengkap dan tidak adanya media pendukung dalam penyampaian informasi ketika konseling. 
Namun pernyataan dari informan pendukung bahwasanya informasi yang diberikan kepada ibu hamil KEK terkait PMT lebih banyak diberikan ketika saat konseling. Informasi yang disampaikan gizi seimbang, kemudian ada juga penjelasan mengenai risiko kehamilan, ASI eksklusif, dan mengenai adanya program pemerintah terkait pemberian makanan tambahan.

Hal ini sejalan dengan teori (Lestari, 2015) bahwa pengetahuan merupakan hasil tahu dan ini terjadi setelah orang melakukan pengindraan terhadap suatu objek tertentu. Pengetahuan atau kognitif merupakan domain yang sangat penting untuk terbentuknya tindakan seseorang. Setiap orang memiliki caracara tertentu dalam menyerap informasi dari luar kedalam memorinya. Sebagian orang mudah menyerap informasi dengan mendengarkan. Mereka belajar dengan menggunakan pendengaran. Selain itu ada juga yang lebih mudah memahami sesuatu dengan melakukan atau mempraktikkannya. Informasi bisa didapat dengan berbagai cara seperti pendidikan kesehatan, pelatihan, konseling, majalah. Maka dapat dilihat bahwa pengetahuan seseorang akan meningkat dengan cara menyerap informasi dari luar.

Selain itu dilihat dari karakteristik informan utama 3 dari 5 informan memiliki pendidikan terakhir SMA dan 2 dari 5 informan memiliki pendidikan terakhir SMP. Pendidikan yang ditempuh oleh informan juga merupakan salah satu faktor yang mempengaruhi pengetahuan. Hal ini sejalan dengan teori (Notoatmodjo, 2010) menyatakan bahwa faktor yang mempengaruhi tingkat pengetahuan seseorang meliputi faktor internal yang terdiri dari pendidikan, minat, pengalaman, dan usia serta faktor eksternal yang terdiri dari ekonomi, informasi, dan kebudayaan lingkungan. Minat merupakan faktor internal dari pengetahuan seseorang.

Apabila seseorang mempunyai pengetahuan yang tinggikan didukung minat yang cukup dari seseorang untuk mengkonsumsi PMT sesuai prosedur yang ada, sesuai dengan apa yang diharapkan. Faktor eksternal juga berpengaruh terhadap pengetahuan yaitu informasi. Penerimaan informasi baru dari tenaga kesehatan, bidan maupun kader akan meningkatkan kesadaran ibu hamil KEK terhadap program PMT akan berpengaruh terhadap perubahan perilaku.
Informasi bisa disajikan dalam media masa maupun melalui kegiatan-kegiatan penyuluhan kesehatan.

Hal ini sejalan dengan penelitian (Dafiu, 2017) yang menyatakan dari 90 responden diketahui bahwa ibu hamil yang mempunyai pengetahuan yang baik dengan status gizi normal yaitu sebesar 84,3\%, sedangkan ibu hamil yang mempunyai pengetahuan yang kurang dengan status gizi yang normal yaitu sebesar 3,9\%. Kesimpulan dalam penelitian ini adalah ada hubungan pengetahuan ibu hamil tentang gizi kehamilan dengan kejadian kurang energi kronik (KEK). Hal yang perlu dilakukan adalah dengan meningkatkan pengetahuan gizi seimbang ibu hamil melalui penyuluhan.

Berdasarkan penelitian yang telah dilakukan kepada triangulasi sumber yaitu staf gizi Puskesmas Karya Wanita Kota Pekanbaru didapatkan hasil bahwasanya staf gizi hanya memberikan konseling setiap ada ibu hamil yang datang ke bagian gizi, informasi yang disampaikan kepada ibu hamil mengenai gizi seimbang, setelah itu staf gizi juga menjelaskan adanya bantuan dari pemerintah berupa makanan tambahan untuk ibu hamil. Menurut peneliti berdasarkan pernyataan diatas bahwasanya masih kurangnya pengetahuan ibu hamil KEK terkait jangka waktu mengonsumsi PMT tersebut sehingga perlunya dukungan tenaga kesehatan terkait pemberian informasi mengenai PMT ini seperti bagaimana cara mengonsumsi PMT dengan baik dan benar serta jangka waktu mengonsumsi PMT dengan menggunakan media kekinian.

\section{Sikap Ibu Hamil KEK terhadap Perilaku Konsumsi PMT}

Sikap ibu hamil KEK terkait PMT sudah bagus dilihat dari pernyataan yang diungkapkan oleh ibu hamil KEK bahwasanya makanan tambahan sangat penting. Kemudian merasa kecewa jika tidak mendapatkan PMT. Namun ibu hamil KEK juga berpendapat bahwasanya jika ada ibu hamil KEK yang tidak mengonsumsi makanan tambahan itu wajar, dikarenakan daya terima setiap ibu hamil itu berbeda-beda. Kemudian berdasarkan hasil wawancara dengan kader mengenai semangat ibu hamil KEK terhadap adanya PMT didapatkan hasil bahwasanya ibu hamil KEK memberikan respon yang baik terhadap program PMT ini. 
Hal ini sejalan dengan teori yang menyatakan bahwasanya sikap terhadap kesehatan adalah pendapat atau penilaian seseorang terhadap hal-hal yang berkaitan dengan pemeliharaan Kesehatan (Notoatmodjo, 2014). Menurut (Mahmuda, 2016) menyatakan bahwa sikap adalah evaluasi atau reaksi perasaan. Sikap seseorang terhadap suatu objek adalah perasaan mendukung atau memihak maupun perasaan tidak mendukung atau tidak memihak pada objek tersebut. Kemudian menurut (Hakim, 2012) menyatakan bahwa sikap dapat dikatakan sebagai kecenderungan efektif suka atau tidak suka pada suatu objek sosial tertentu.

Sikap ibu hamil KEK yang positif terkait PMT ini merupakan suatu bentuk penerimaan ibu hamil terhadap program tersebut, sehingga program ini bisa berlanjut sampai ibu hamil KEK tidak berada dalam kondisi KEK lagi. Hal ini merupakan salah satu bagian penting terhadap perilaku ibu hamil KEK dalam mengonsumsi MT tersebut. namun dalam hal ini sikap tidak ada hubungannya dengan kepatuhan ibu hamil KEK dalam mengonsumsi PMT yang telah diberikan.

Hal ini sejalan dengan penelitian (Gagu, 2018) yang membahas mengenai faktorfaktor yang mempengaruhi kepatuhan konsumsi makanan tambahan biskuit pada ibu hamil di Kota Pare-Pare Sulawesi Selatan didapatkan hasil bahwasanya tidak ada hubungan antara sikap dengan kepatuhan ibu dalam mengkonsumsi makanan tambahan tersebut.

\section{Dukungan Suami Ibu Hamil KEK terhadap Perilaku Konsumsi PMT}

Berdasarkan penelitian yang telah dilakukan didapatkan hasil bahwasanya 5 ibu hamil KEK yang menjadi informan menyatakan suami sangat senang dan sangat mendukung dengan adanya program pemberian makanan tambahan ini (PMT), kemudian suami selalu memberikan dukungan seperti motivasi serta dukungan secara langsung terkait memilih makanan yang sehat yang akan dikonsumsi oleh ibu hamil. Selain itu berdasarkan hasil wawancara dengan kader selaku informan pendukung didapatkan hasil bahwasanya respon suami terhadap PMT sudah bagus dan juga dukungan suami dalam meningkatkan kesehatan ibu sangat baik, misalnya suami ikut serta dalam mengambil PMT ke rumah kader.
Hal ini sejalan dengan teori Sarafino (2011) menyebutkan bahwa terdapat 4 jenis dukungan suami, yang pertama yaitu dukungan emosional melibatkan ekspresi empati, perhatian, pemberian semangat, atau bantuan emosional. Dukungan emosional sesuai dengan teori Rukiyah (2014) bahwa suami merupakan orang yang paling penting bagi ibu hamil dalam memberikan perhatian dan mengasihi pasangannya selama hamil.

Selain itu juga didukung oleh penelitian terdahulu oleh Puspitasari, I. A (2019) mengenai analisis faktor yang berhubungan dengan perilaku ibu hamil kurang energi kronis dalam melaksanakan program pemberian makanan tambahan didapatkan hasil bahwasanya ada hubungan antara pendidikan, tingkat pengetahuan, dan dukungan suami dengan perilaku ibu hamil KEK dalam melaksanakan program PMT.

Berdasarkan pernyataan diatas dapat disimpulkan bahwasanya dukungan suami merupakan salah satu faktor dalam membentuk perilaku ibu hamil untuk mengonsumsi PMT yang diberikan oleh Pihak Puskesmas Karya Wanita Kota Pekanbaru. Hal ini dapat dilihat bahwasanya semua suami ibu hamil KEK yang menjadi informan penelitian memberikan dukungan bersifat positif dan selalu mendukung khususnya dalam menentukan makanan yang sehat bagi ibu hamil KEK. Dengan adanya dukungan suami, tenaga kesehatan juga dapat mengikutsertakan suami disaat ibu hamil memeriksakan kehamilan di Puskesmas sehingga suami juga mendapatkan informasi terkait kehamilan serta informasi terkait PMT yang diberikan oleh tenaga kesehatan.

\section{Kepatuhan Ibu Hamil KEK terhadap Perilaku Konsumsi PMT}

Dari hasil wawancara 3 dari 5 ibu hamil KEK menjawab mereka rutin mengonsumsi makanan tambahan tersebut dan tidak pernah lupa, kemudian 3 dari 5 ibu hamil KEK juga mengatakan bahwasanya makanan tambahan yang dikonsumsi tidak pernah bersisa selalu habis. Selain itu mengenai cara mengatasi kebosanan dalam mengonsumsi makanan tambahan sebagian besar ibu hamil KEK mengatakan tidak pernah bosan mengonsumsi makanan tambahannya.

Berdasarkan hasil observasi didapatkan hasil bahwasanya dari hasil observasi dapat dilihat bahwasanya jika ibu hamil KEK yang 
memiliki balita, biskuit untuk balita juga sudah tersedia. Namun 2 dari 5 ibu hamil KEK tidak selalu mengonsumsi PMT yang telah diberikan, hal ini dapat dilihat pada saat penelitian berlangsung peneliti menemukan ketidaksesuaian antara pernyataan yang disampaikan oleh informan dengan jumlah biskuit informan, maksudnya yang seharusnya biskuit tersebut sudah habis dalam waktu 1 bulan namun kenyataannya masih ada biskuit yang tersisa.

Hal ini didukung oleh pernyataan Sarlito W. Sarwono (2009) bahwa kepatuhan merupakan salah satu jenis dari pengaruh sosial yaitu ketika seseorang menaati dan mematuhi permintaan orang lain untuk melakukan tingkah laku tertentu karena adanya unsur power. Power ini diartikan sebagai suatu kekuatan atau kekuasaan yang memiliki pengaruh terhadap seseorang atau lingkungan tertentu.

Kemudian sejalan dengan penelitian Rahmawati, D. A (2015) yang menyatakan kepatuhan merupakan sikap disiplin atau perilaku taat terhadap suatu perintah maupun aturan yang telah ditetapkan dengan penuh kesadaran. Kepatuhan sebagai perilaku positif dinilai sebagai sebuah pilihan. Artinya individu memilih untuk melakukan, mematuhi, merespons secara kritis terhadap aturan, hukum, norma sosial, permintaan maupun keinginan dari seseorang yang memegang otoritas ataupun peran penting. Ada beberapa faktor yang mempengaruhi ketidakpatuhan seseorang seperti pemahaman tentang instruksi, kualitas interaksi, dukungan sosial dan keluarga, serta keyakinan, sikap, dan kepribadian.

Berdasarkan pernyataan diatas, peneliti menyimpulkan bahwa tingkat kepatuhan 3 dari 5 ibu hamil KEK dalam mengkonsumsi PMT sudah baik. Hal tersebut dapat dilihat dari sisa PMT ketika peneliti melakukan penelitian sesuai dengan kapan PMT diberikan. Namun 2 dari 5 ibu hamil KEK masih belum patuh dalam mengonsumsi PMT yang telah diberikan, kendala yang ditemukan ibu hamil KEK mengatakan bahwa sering lupa untuk mengonsumsi PMT tersebut.

\section{Penerimaan Ibu Hamil KEK terhadap Perilaku Konsumsi PMT}

Selanjutnya berdasarkan hasil wawancara dengan informan utama mengenai bagaimana bentuk makanan tambahan yang diterima mulai dari tekstur, warna dan rasa didapatkan hasil 3 dari 5 itu hamil KEK mengatakan bahwasanya tidak ada masalah dalam bentuk dan teksturnya. Kemudian terkait rasa dari PMT tersebut 3 dari 5 ibu hamil KEK mengatakan rasa biskuit tersebut enak dan tidak bikin enek. Namun 2 dari 5 ibu hamil KEK mengatakan bahwasanya rasa dari biskuit tersebut terlalu manis dan bikin enek, mereka mengatakan bahwa mereka lebih menyukai rasa coklat.

Berdasarkan hasil wawancara dengan informan pendukung mengenai bagaimana ibu hamil dalam mengambil makanan tambahan tersebut apakah sudah sesuai jadwal dan apakah ada yang tidak mengambil, didapatkan hasil bahwasanya daya terima dari ibu hamil itu beda-beda, jika mereka suka mereka akan datang tepat waktu atau ada juga yang datang sedikit terlambat, namun jika mereka tidak suka mereka tidak akan datang lagi. Hal ini berkaitan dengan penerimaan ibu hamil KEK bahwasanya 3 dari 5 ibu hamil KEK selalu datang kembali untuk mengambil PMT jika sudah habis. Berdasarkan hasil observasi dapat dilihat bahwasanya daya terima ibu hamil KEK dalam mengonsumsi PMT ini masih kurang, dapat dilihat bahwasanya 2 dari 5 ibu hamil KEK masih menyisakan makanan tambahannya.

Hal ini sejalan dengan pernyataan menurut Pertemuan Ilmiah Nasional (2007) daya terima makanan adalah penerimaan terhadap makanan yang disajikan dapat diterima oleh konsumen. Tolak ukur keberhasilan penyelenggaraan makanan adalah makanan yang disajikan dapat diterima dan makanan tersebut habis termakan tanpa meninggalkan sisa makanan. Daya terima merupakan tolak ukur atas kepuasan dari pasien.

\section{Dukungan Tenaga Kesehatan terhadap Perilaku Konsumsi PMT (KIE)}

Berdasarkan penelitian yang telah dilakukan didapatkan hasil bahwasanya 4 dari 5 ibu hamil KEK mengatakan penjelasan yang disampaikan oleh pihak Puskesmas Karya Wanita Kota Pekanbaru sudah bagus, petugas kesehatan menjelaskan terkait gizi ibu hamil serta penjelasan mengenai makanan tambahan. Namun 4 dari 5 informan utama juga mengatakan informasi yang diberikan melalui konseling saja. Selanjutnya mengenai informasi sebelum pelaksanaan PMT 4 dari 5 ibu hamil KEK mengatakan tidak pernah mendapatkan 
informasi sebelum pelaksanaan PMT dilakukan. Ibu hamil KEK mengetahui adanya pemberian makanan tambahan ketika melakukan pemeriksaan kehamilan di Puskesmas Karya Wanita Kota Pekanbaru. Kemudian untuk motivasi biasanya petugas Puskesmas maupun kader sudah ada memberikan motivasi agar ibu hamil mau mengonsumsi makanan tambahan yang telah diberikan.

Selain itu hasil wawancara mendalam dengan staf gizi, bidan, dan petugas promosi kesehatan mengenai informasi yang diberikan petugas kesehatan sebelum pemberian makanan tambahan, didapatkan hasil bahwasanya petugas kesehatan mengatakan setiap ibu hamil yang kontak dengan petugas akan diberikan informasi terkait gizi seimbang, baik itu ibu hamil KEK maupun tidak KEK, mengenai pengambilan PMT petugas kesehatan juga mengatakan informasi yang diberikan mengenai tujuan pemberian PMT. Pemberian informasi ada melalui kader jika ibu hamil tidak periksa ke Puskesmas, dan ada juga kerjasama dengan faskes seperti bidan praktik mandiri, kemudian ada grup khusus ibu hamil.

Kemudian berdasarkan wawancara mendalam dengan kader selaku informan pendukung mengenai pengambilan PMT tersebut didapatkan hasil sebagian besar kader mengatakan bahwasanya ibu hamil yang berada diwilayah kerja mereka sudah mendapatkan informasi terkait PMT tersebut. Kemudian motivasi yang selalu diberikan kepada ibu hamil bahwasanya kader selalu mengingatkan ibu hamil untuk melakukan pemeriksaan ke Puskesmas dan menjelaskan bahwasanya ada pemberian makanan tambahan juga.

Hal ini sejalan dengan pernyataan (Salamun \& Minarti, 2019) bahwa peran petugas kesehatan adalah suatu kegiatan yang diharapkan dari seorang petugas kesehatan yang memberikan pelayanan kesehatan kepada masyarakat untuk meningkatkan derajat kesehatan masyarakat. Adapun peran tenaga kesehatan dalam promosi kesehatan menurut (Salamun \& Minarti, 2019) yaitu peran sebagai advokator (pendekatan yang mempunyai pengaruh terhadap keberhasilan suatu program atau kegiatan), peran sebagai edukator (memberikan pendidikan kesehatan dan konseling dalam asuhan dan pelayanan kesehatan di setiap sistem pelayanan kesehatan agar mereka mampu memelihara dan meningkatkan kesehatan mereka), peran sebagai fasilitator (tenaga kesehatan mempunyai tanggung jawab untuk menciptakan, mengondisikan iklim kelompok yang harmonis, serta memfasilitasi terjadinya proses saling belajar dalam kelompok, peran sebagai motivator (upaya yang dilakukan tenaga kesehatan sebagai pendamping adalah menyadarkan dan mendorong kelompok untuk mengenali potensi dan masalah, dan dapat mengembangkan potensinya untuk memecahkan masalah itu).

Hal ini juga didukung oleh teori Maulita (2014) bahwa dukungan tenaga kesehatan merupakan sumber dukungan sosial yang memiliki peran penting untuk mengubah perilaku atau keadaan. Sesuai dengan penelitian sebelumnya (Yuda, 2017) bahwa pendampingan konsumsi PMT pada ibu hamil KEK mempunyai pengaruh terhadap kepatuhan ibu hamil dalam mengonsumsi PMT ( $\mathrm{p}$ value $0,001)$.

Namun pada jawaban dari hasil wawancara ibu hamil KEK mengatakan hanya mendapatkan informasi melalui konseling, tidak adanya penyuluhan terkait PMT untuk saat ini. Menurut peneliti pemberian informasi yang diberikan tenaga kesehatan perlu ditingkatkan lagi dengan menggunakan metode kekinian sehingga lebih mudah dipahami dan diterima oleh ibu hamil KEK.

\section{Pendistribusian PMT}

Berdasarkan hasil wawancara dengan informan pendukung bahwasanya pada masa pandemi covid-19 ini sistem pendistribusian PMT mengalami penghambatan dikarenakan ibu hamil tidak boleh datang ke Puskesmas, sehingga banyaknya penumpukan biskuit di gudang. Namun pada bulan Juli tahun 2020 pihak Puskesmas Karya Wanita yaitu petugas gizi meminta bantuan kader posyandu untuk mendata ibu hamil yang ada diwilayah kerja kader tersebut, setelah itu pihak Puskesmas langsung turun menggunakan Ambulance untuk membagi-bagikan biskuit kepada ibu hamil di wilayah kerja Puskesmas Karya Wanita. Untuk pendistribusian PMT saat ini sudah sesuai dengan juknis yang telah ditetapkan, meskipun semua ibu hamil diberikan PMT baik itu ibu hamil KEK, gakin, dan ibu hamil normal, namun prioritas utama tetap ibu hamil KEK.

Berdasarkan Juknis (2017) kriteria ibu hamil yang mendapatkan PMT ialah ibu hamil dari keluarga miskin dan ibu hamil yang 
berisiko KEK dengan LILA $<23,5 \mathrm{~cm}$, apabila persediaan makanan tambahan tidak mencukupi, sasaran PMT diprioritaskan pada ibu hamil KEK dari keluarga miskin dan ibu hamil KEK.

\section{KESIMPULAN DAN SARAN}

Pengetahuan ibu hamil KEK terkait jangka waktu mengkonsumsi PMT masih kurang hal ini dapat dilihat bahwa banyak ibu hamil KEK yang tidak mengetahui sampai kapan makanan tambahan itu dikonsumsi dan juga tidak mengetahui berapa banyak makanan tambahan dikonsumsi setiap harinya, Sikap ibu hamil KEK dan dukungan suami terkait PMT sudah bagus hal ini dapat dilihat dari semangat ibu hamil KEK dalam menerima makanan tambahan yang diberikan oleh tenaga kesehatan maupun kader. Kepatuhan ibu hamil KEK yang masih kurang dapat dilihat dari masih adanya ibu hamil KEK yang mengkonsumsi PMT tidak sesuai jadwal dikarenakan lupa, Penerimaan ibu hamil KEK terkait PMT masih kurang karena masih adanya ibu hamil KEK yang kurang menyukai PMT yang telah diberikan, Informasi yang diberikan oleh tenaga kesehatan ketika konseling perlu ditingkatkan lagi dengan menggunakan media digital seperti seperti video.

Pendistribusian PMT saat ini sudah sesuai juknis yang telah ditetapkan, untuk pendistribusian staf gizi berkolaborasi dengan kader dalam mendata ibu hamil KEK, kemudian staf gizi mendistribusikan PMT secara langsung. Saran kepada Dinas Kesehatan untuk melakukan bimbingan teknis secara rinci kepada petugas kesehatan tentang PMT, bagi Puskesmas diharapkan kepada staf gizi dan bidan KIA untuk lebih meningkatkan lagi dalam pemberian informasi terkait PMT kepada ibu hamil KEK. Meningkatkan peran serta kader dalam membantu mendistribusikan PMT, bagi peneliti selanjutnya diharapkan dapat mengevaluasi program PMT sehingga dapat mengetahui bagaimana program PMT tersebut dilaksanakan.

\section{DAFTAR PUSTAKA}

Andiyani, \& Susilawati. (2019). Kejadian Kekuranagan Energi Kronik (KEK) pada Ibu hamil. Jurnal Kesehatan, 10(3), 220 227. https://doi.org/http://dx.doi.org/ 10.35730/jk.v10i3.417.g493.

Andriani, Z. (2015). Gambaran Status Gizi Ibu
Hamil Berdasarkan Ukuran Lingkar Lengan. 57.

Azizah, A., \& Adriani, M. (2018). Tingkat Kecukupan Energi Protein Pada Ibu Hamil Trimester Pertama Dan Kejadian Kekurangan Energi Kronis. KKetdiabaráasan Penelitian ini Indonesia, 12(1), 21. https://doi.org/ 10.20473/mgi.v12i1.21-26.

Dafiu, T. R. (2017). Hubungan Pengetahuan Ibu Hamil Tentang Gizi Kehamilan dengan Kejadian Kurang Energi Kronik (KEK) pada Kehamilan di Kota Yogyakarta. Poltekkes Kemenkes Yogyakarata.

Gagu, N. (2018). Faktor-Faktor yang Mempengaruhi Kepatuhan Konsumsi Biskuit Makanan Tambahan Biskuit pada Ibu Hamil di Kota Pare-Pare Sulawesi Selatan. Universitas Hasanuddin.

Hakim, L. (2012). Internalisasi Nilai-Nilai Agama Islam Dalam Pembentukan Sikap dan Perilaku Siswa Sekolah Dasar Islam Terpadu Al-Muttaqin Kota Tasikmalaya. Jurnal Pendidikan Agama Islam -Ta'lim, 10(1), 67-77. http://jurnal.upi.edu/ file/5_Penanaman_Nilai.pdf\%0Ahttps:// media.neliti.com/media/publications/108 820-ID-penerapan-strategi-pembelajarankreatif.pdf.

Kementerian Kesehatan RI. (2017). Petunjuk Teknis PMT. In Petunjuk Teknis PMT.

Kesehatan, D. (2018). LKjIP Pemerintah Tahun 2018. Laporan Kinerja Instansi Pemerintah Tahun 2018, 1-220.

Lestari, T. (2015). Kumpulan Teori Untuk Kajian Pustaka Penelitian Kesehatan (Cet. 1). Nuha Medika.

Mahmuda, N. (2016). Sikap Santri Terhadap Kesehatan Reproduksi Remaja di Pondok Pesantren Putri Al Manaar Muhammadiyah 1 Pemalang. Fakultas Psikologi UMP, 2009.

Mangalik, G., Koritelu, R. T., Amah, M. W., Junezar, R., Kbarek, O. P. I., \& Widi, R. (2019). Program Pemberian Makanan Tambahan:Studi Kasus Pada Ibu Hamil Dengan Kurang Energi Kronis Di Puskesmas Cebongan Salatiga. Jurnal Ilmu Keperawatan Dan Kebidanan, 10(1), 111. https://doi.org/10.26751/ jikk.v10i1.537.

Manik, M., \& Rindu, R. (2017). Faktor yang Berpengaruh terhadap Kenaikan Berat Badan Ibu Hamil dengan KEK pada 
Trimester III. Jurnal Ilmiah Kesehatan, 16(2), 23-31. https://doi.org/10.33221/ jikes.v16i2.10.

Notoatmodjo, S. (2010). Ilmu Perilaku Kesehatan. Rineka Cipta.

Notoatmodjo, S. (2014). Promosi Kesehatan dan Perilaku Kesehatan. Rineka Cipta.

Salamun, \& Minarti. (2019). Hubungan Peran Petugas Kesehatan, Sumber Informasi terhadap Perawatan Payudara Ibu Nifas.
Jurnal Aisyiyah Medika, 4. http://jurnal.stikes- aisyiyah-palembang. ac.id/index.php/JAM/article/view/216.

Yuda, M. P. (2017). Pengaruh Pendampingan Konsumsi PMT melalui SMS terhadap Kepatuhan Konsumsi PMT pada Ibu Hamil KEK di Wilayah Kerja Puskesmas Tegowanu dan Puskesmas Gubug 1. Poltekkes Kemenkes Semarang. 